\title{
Evaluation of biomass quality in short-rotation bamboo (Phyllostachys pubescens) for bioenergy products
}

Seung Gon Wi', Dae-Seok Lee ${ }^{1}$, Quynh Anh Nguyen ${ }^{1}$ and Hyeun-Jong Bae ${ }^{1,2^{*}}$

\begin{abstract}
Background: In order to improve the availability of biomass, the concept of growing high yield biomass with short rotations and intensive culture has been introduced. Bamboo has become a feedstock of potential interest for future energy production due to its high productivity and short rotation time. The growth age of biomass is an important factor affecting the efficiency of bioconversion and pretreatment for bioenergy production. In this regard, more information is required on the morphology and chemical composition of bamboo for short-rotation biomass production. In this study, we used a compositional assay to compare a bamboo of two different growth ages.

Results: Bamboo of two different ages showed characteristics patterns of morphology, chemical composition, and bioconversion. In young-age (2-month-old) bamboo, the pattern of tissue organization was similar to that of oldage (3-year-old) bamboo, indicating that the former had reached its full height. There were significant differences between young-age and old-age bamboo in terms of chemical composition. The glucose contents in old-age bamboo did not differ significantly among its internodes. For young-age bamboo, the lignin contents were 14.6-18.3\%, whereas those of old-age bamboo were considerably higher, ranging from 25.4 to $27.1 \%$ with increasing syringylto-guaiacyl ratio. The yield of total sugars following enzymatic hydrolysis of young-age bamboo was approximately eight times. However, following hydrogen peroxide-acetic acid pretreatment, the results of separate hydrolysis and fermentation and simultaneous saccharification and fermentation did not differ significantly between young-and old-age bamboo. However, ethanol production was higher in 2-month old than in 3-year old from initial raw biomass.

Conclusion: Our data show that the production of total sugar from raw material was high in young bamboo with low lignin content. With respect to short-rotation biomass, bamboo culm harvested after termination of height growth is more appropriate for use as a biomass resource to achieve a high yield for bioconversion process.
\end{abstract}

Keywords: Bamboo, Bioethanol, Biomass, Cell wall composition, Short-rotation biomass

\section{Background}

As a consequence of increased energy demand and global warming, sustainability and green growth are considered key concepts for public and industrial growth. In 2014, Korea consumed 0.27 billion tons of oil equivalent (TOE) and is the 9th highest energy consumer and 7th highest carbon dioxide emitter in the world [1, 2]. Fossil fuelbased energy resources, such as petroleum (37.1\%), coal

\footnotetext{
*Correspondence: baehj@chonnam.ac.kr

2 Department of Bioenergy Science and Technology, Chonnam National

University, Gwangju 500-757, Republic of Korea

Full list of author information is available at the end of the article
}

(29.9\%), and natural gas (16.9\%), account for approximately $84 \%$ of the primary energy consumption [1]. In contrast, in 2014, the production of bioenergy as sustainable alternatives to fossil fuel-based energy resources was represented approximately by 2.8 million TOE, which was only approximately $1 \%$ of primary energy consumption [3]. Korea has limited biomass resources and the high cost of biofuels is a major barrier to their widespread use [1]. Therefore, increasing efforts are being made to identify new suitable biomass resources for biofuels production [4-8]. 
In order to improve the availability of biomass, the concept of growing high yield biomass with short rotations and intensive culture has been introduced $[9,10]$. Bamboo has become a feedstock of potential interest for future energy production due to its high productivity, short-rotation and high economic value, and advantage for sustainable management $[11,12]$. Bamboo has been used in approximately 1500 commercial application, including house, panel or composites, mat, chopsticks, sticker, charcoal or active carbon, and pulp and paper making [13]. Bamboo is a grass biomass with the hollow internode and the scattered vascular bundles throughout the stem. It belongs to the family Gramineae, which includes over 75 genera and 1250 species [13]. Worldwide, the area planted with bamboo and its annual production are estimated to be $220,000 \mathrm{~km}^{2}$ and 15-20 million tons, respectively [14]. Bamboo, a superior species for carbon storage, requires only 5 years to grow from shoots to mature culms [15]. In general, the development of bamboos can be classified into two growth periods [16-18]. The first stage is culm height growth with fast growth and high biomass accumulation within few months. After their full height growth, the second stage starts culms, increasing in strength and accumulating dry mass until they are mature.

It is well known that the diversity in physical and chemical properties of biomass present difficulties and challenges encountered during the processes for fuel or energy use [12]. For efficiently bioconversion of bamboo, various pretreatment methods have been used [19, 20]; however, none of these methods are cost-effective for large-scale applications. The development of a highly efficient and environmentally friendly process for the hydrolysis of cellulose into reducing sugars could be one of the key technologies for large-scale use of cellulosic biomass. In order to attain this goal, hydrogen peroxideacetic acid (HPAC) pretreatment has been proposed and conveniently established using a mixture of green chemicals; acetic acid and hydrogen peroxide [21]. In this study, we used the HPAC pretreatment method for processing bamboo.

Growth age is an important factor affecting the efficiency of bamboo pretreatment [19]. In this regard, more information is required on the morphology and chemical composition of bamboo for short-rotation biomass production. In this study, we used a compositional assay to compare a bamboo of two different growth ages. We found a correlation between two groups for chemical composition. These compositional parameters influenced the yield obtained following pretreatment and enzymatic hydrolysis for bioenergy production.

\section{Results and discussion}

\section{Biomass productivity}

The productivity of bamboo was assessed on the basis of the fresh and dry weight. The biomass weight at various heights is presented in Fig. 1. The fresh and dry weight results for 2-month-old and 3-year-old bamboo showed the same trend, a decrease from the basal section $(1 \mathrm{~m})$ to the top section (12 or $13 \mathrm{~m}$ ), and a decrease of biomass weight in the top section due to smaller diameter and thinner wall. The total dry weight of 3-year-old bamboo $(8.43 \mathrm{~kg} / \mathrm{stem})$ was two-fold higher than 2 -monthold bamboo $(4.08 \mathrm{~kg} / \mathrm{stem})$; however, there was only a slight difference in total fresh weight between 3-yearold $(12.38 \mathrm{~kg} / \mathrm{stem})$ and 2 -month-old $(14.88 \mathrm{~kg} / \mathrm{stem})$ bamboo. The moisture content in the 2-month-old and 3 -year-old bamboo was $69-74$ and $27-34 \%$, respectively.
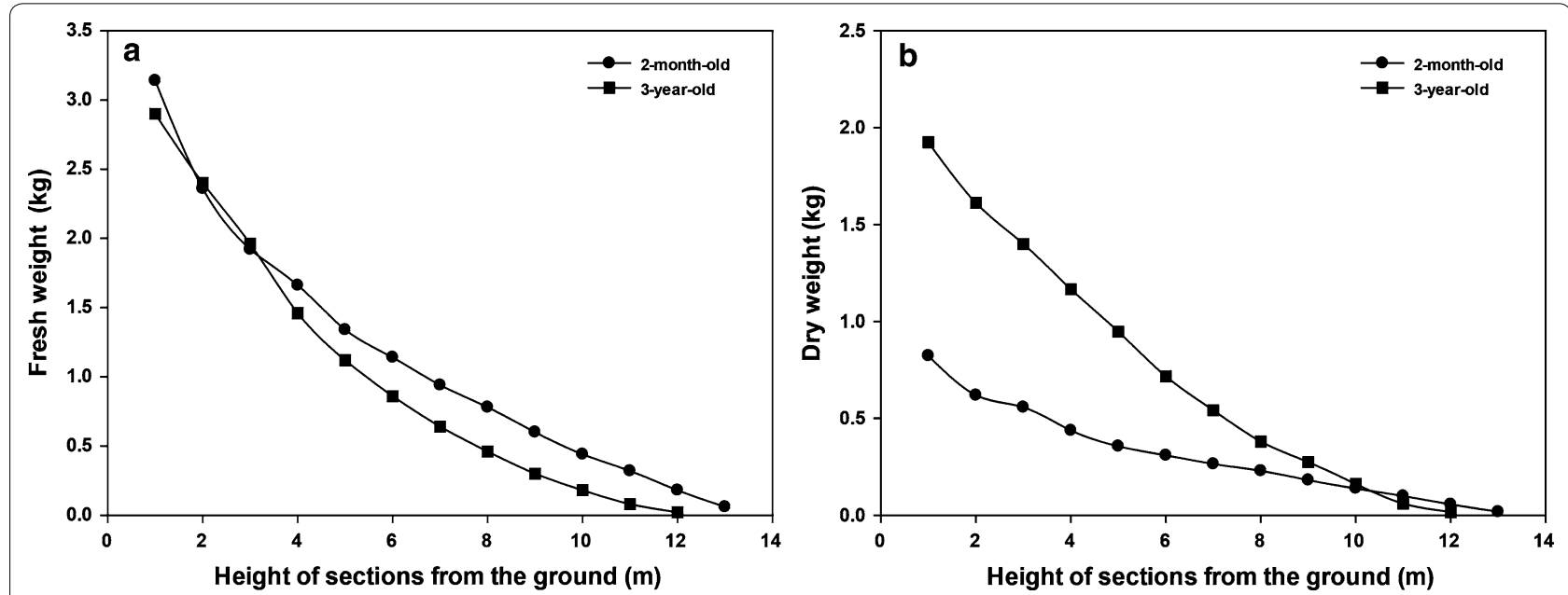

Fig. 1 Relationships between fresh (a) and dry (b) weight and against height of each section from the ground (see "Methods" for detail). Each value is expressed as the average of three independent experiments 


\section{Anatomical characteristics}

As anatomical features directly affect bamboo's physical and mechanical properties, we have conducted a comparative analysis of the anatomical characteristic between 2-month-old and 3-year-old bamboo. Autofluorescence was used to examine the morphology and lignin pattern in bamboo materials. Figure 2 shows a cross-section of bamboo stem. The internode of a bamboo stem was mainly consisted of epidermis, cortex, parenchyma, and vascular bundles. The anatomical aspects of 2-month-old bamboo were mostly similar to those of the 3-year-old bamboo; however, the cell walls of parenchyma, vascular bundle, and sclerenchyma were considerably more thickened. Fiber wall thickness did not differ significantly at different stem heights; however, there was an increase in thickness with the increase of age. Vascular bundles were surrounded by the bundle sheaths, which are distributed densely in the outer region and sparsely in the inner region. In both 2-month-old and 3-year-old bamboo, the lowest mean density of vascular bundles was in the low regions of the stem. However, the frequency of vascular bundles did not differ significantly with age. Lignin distribution was determined by using fluorescence microscopy (Fig. 3). All the tissues showed blue fluorescence after UV irradiation (Fig. 3a), but lost their autofluorescence after
HPAC pretreatment (Fig. 3b). At longer exposure times $(1 / 2 \mathrm{~s})$, weak autofluorescence was detected in the middle lamella of parenchyma cells and bundle sheaths. The variation in anatomical characteristics along the bamboo column height and age presented in this study was similar to that of Huang et al. [22].

\section{Chemical composition}

The chemical composition of biomass is highly important in terms of bio-based application and variation in the relative proportions of different chemicals can influence bioenergy yield [23]. Furthermore, the chemical composition of biomass varies according to developmental stage $[8,24]$. We analyzed samples collected from 2-month-old to 3-year-old bamboo stems at three different heights above ground level $(1,6$, and $11 \mathrm{~m})$ based on enzymatic hydrolysis data (Fig. 4), compared of the composition of bamboo cell wall (Table 1). There were significant differences between 2-month-old and 3-year-old bamboo in the contents of ash, organic solvent extractives, carbohydrate, and lignin. The contents of ash and carbohydrate in 2-month-old bamboo were higher than those in 3-yearold bamboo. However, the contents of organic solvent extractives and lignin were higher in 3-year-old bamboo. The carbohydrate contents of 2-month-old bamboo were

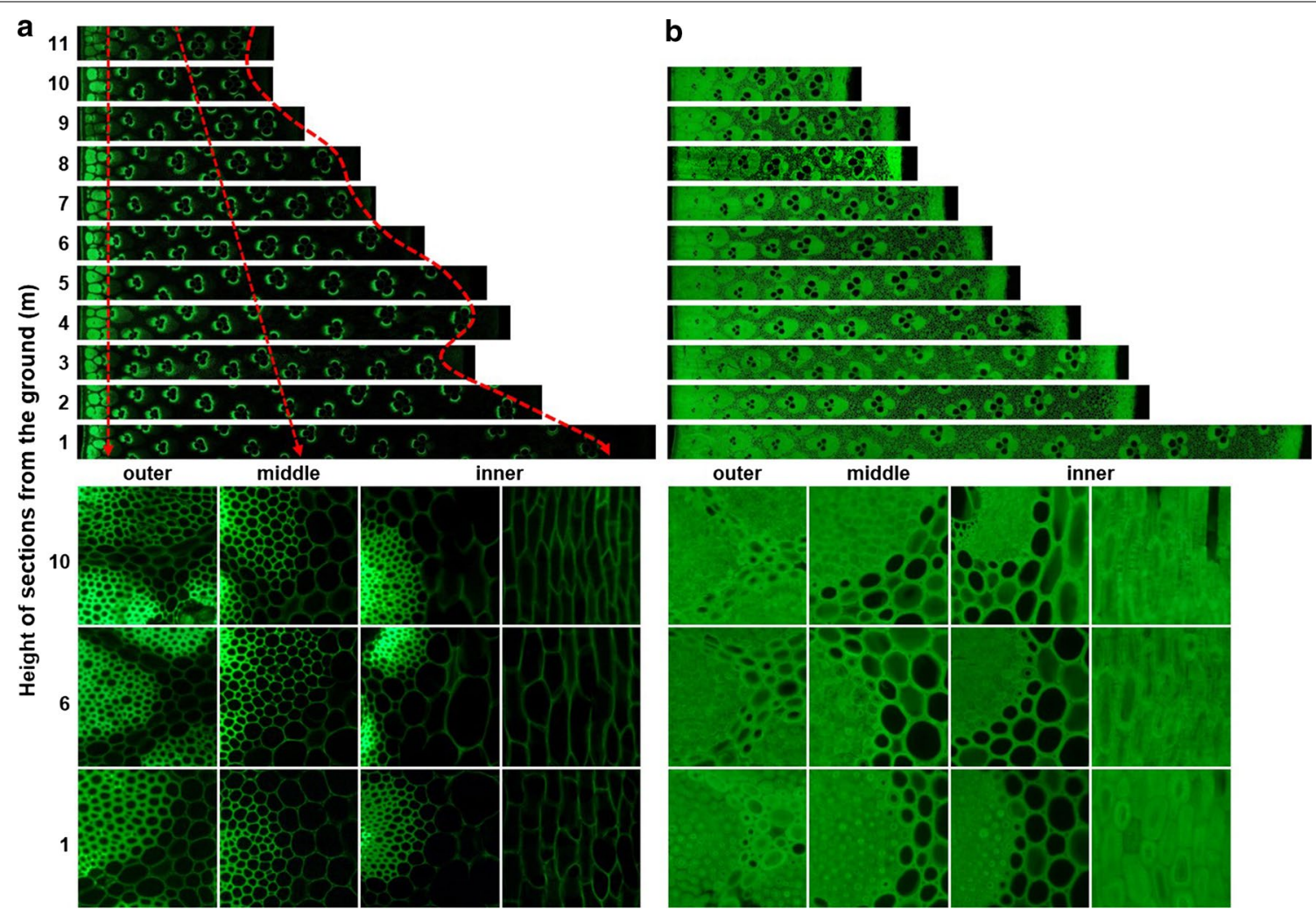

Fig. 2 Fluorescence microscopy images of a cross-section through the section height of 2-month-old (a) and 3-year-old (b) bamboo 


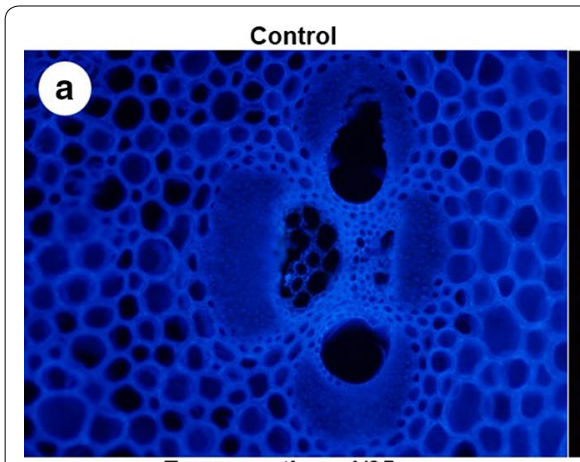

Exposure time: $1 / 35 \mathrm{~s}$

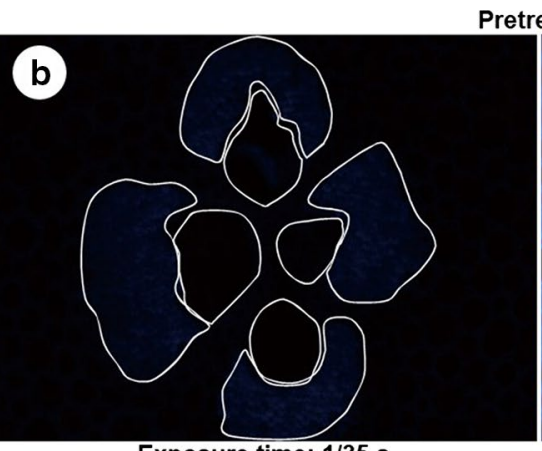

Exposure time: $1 / 35 \mathrm{~s}$
Pretreated

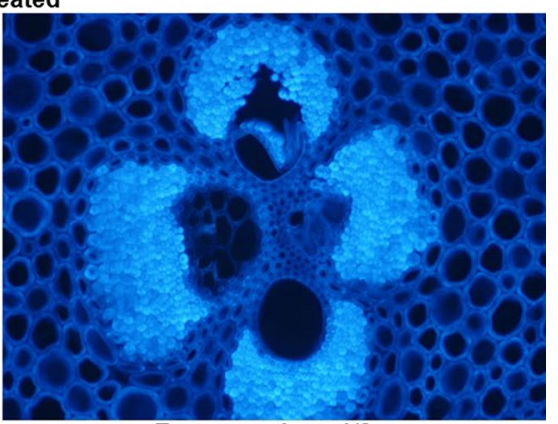

Exposure time: $1 / 2 \mathrm{~s}$

Fig. 3 Fluorescence microscopy images of non-pretreated and hydrogen peroxide-acetic acid (HPAC) pretreated bamboo. All tissues showing autofluorescence after UV irradiation (a). Autofluorescence lost in all tissues after HPAC pretreatment (b)
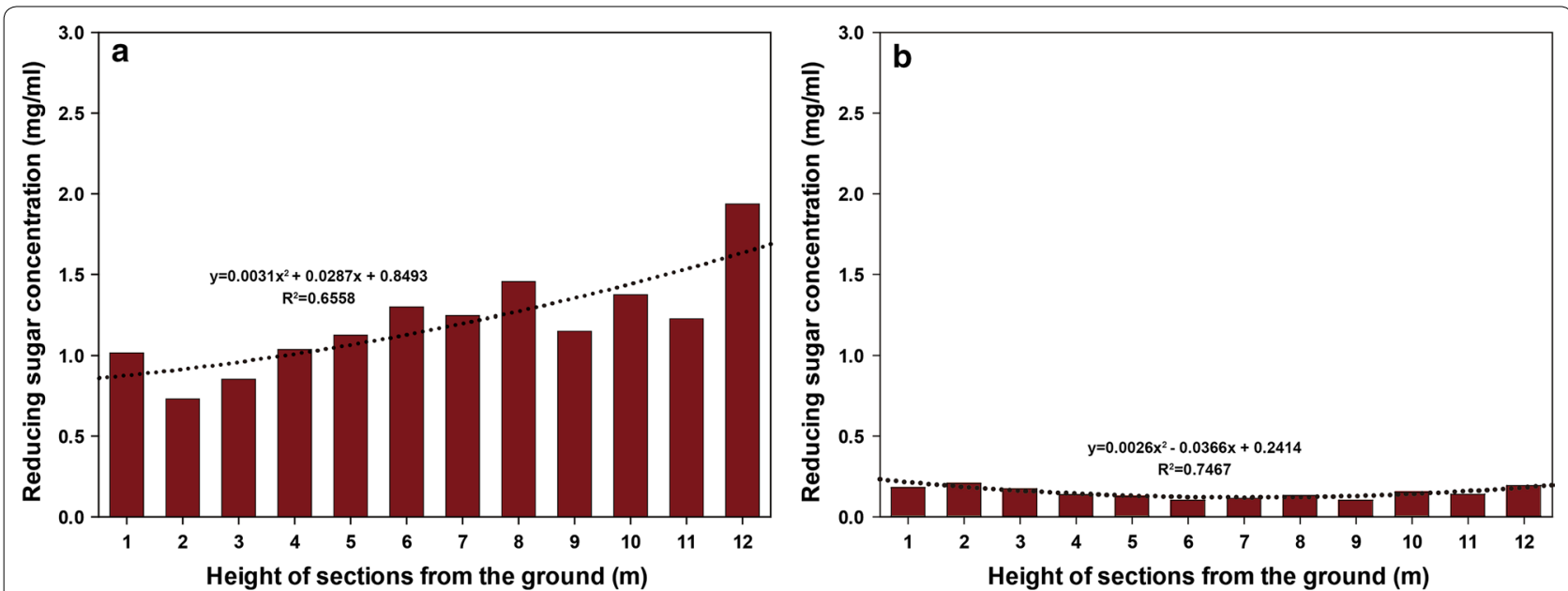

Fig. 4 Changes with stem height in the concentrations of reducing sugar with stem height in 2-month-old (a) and 3-year-old (b) bamboo. Each value is expressed as the average of three independent experiment

Table 1 Compositional analysis of 2-month-old and 3-year-old bamboo

\begin{tabular}{llllllll}
\hline Total biomass (\%) & $\begin{array}{l}\text { Position height } \\
\text { from ground }(\mathbf{m})\end{array}$ & Ash (\%) & OSE (\%) & $\begin{array}{l}\text { Carbohydrate } \\
(\%)\end{array}$ & & & \multicolumn{2}{l}{ Lignin (\%) } & \\
\cline { 4 - 7 } & & & & & AIL & ASL & Total \\
\hline 2-month old & 01 & $3.15 \pm 0.06^{\mathrm{a}}$ & $1.65 \pm 0.09^{\mathrm{a}}$ & $82.17 \pm 0.59^{\mathrm{c}}$ & $15.83 \pm 0.89^{\mathrm{b}}$ & $2.46 \pm 0.02^{\mathrm{a}}$ & $18.29 \pm 0.89^{\mathrm{b}}$ \\
& 06 & $4.01 \pm 0.11^{\mathrm{b}}$ & $1.75 \pm 0.18^{\mathrm{a}}$ & $80.74 \pm 0.41^{\mathrm{b}}$ & $12.31 \pm 0.73^{\mathrm{a}}$ & $2.99 \pm 0.10^{\mathrm{b}}$ & $15.30 \pm 0.63^{\mathrm{a}}$ \\
& 11 & $5.39 \pm 0.13^{\mathrm{c}}$ & $2.46 \pm 0.18^{\mathrm{b}}$ & $78.67 \pm 0.26^{\mathrm{a}}$ & $11.03 \pm 0.63^{\mathrm{a}}$ & $3.60 \pm 0.10^{\mathrm{c}}$ & $14.63 \pm 0.57^{\mathrm{a}}$ \\
& 01 & $1.36 \pm 0.03^{\mathrm{b}}$ & $5.54 \pm 0.28^{\mathrm{a}}$ & $71.85 \pm 2.36$ & $23.55 \pm 0.79$ & $1.87 \pm 0.08$ & $25.41 \pm 0.84$ \\
3-year old & 06 & $1.13 \pm 0.10^{\mathrm{a}}$ & $6.85 \pm 0.43^{\mathrm{b}}$ & $71.37 \pm 2.45$ & $23.43 \pm 1.01$ & $2.03 \pm 0.11$ & $25.46 \pm 1.06$ \\
& 11 & $1.15 \pm 0.06^{\mathrm{a}}$ & $4.75 \pm 0.16^{\mathrm{a}}$ & $69.89 \pm 2.63$ & $24.99 \pm 0.72$ & $2.13 \pm 0.16$ & $27.13 \pm 0.76$ \\
\hline
\end{tabular}

If the ANOVA showed a significant difference among sample means, Scheffe's multiple comparison test was used to determine differences. Values indicated by the same lower case letter are not significantly different $(a=0.01)$. Scheffe: $\mathrm{a}<\mathrm{b}<\mathrm{c}$

AIL acid-insoluble lignin, ASL acid-soluble lignin, OSE organic solvent extractives

78.7-82.2\%, whereas those of 3-year-old bamboo was $69.9-71.9 \%$. The results of monomeric sugar and lignin analyses are shown in Table 2. Glucose and xylose were identified as major carbohydrates in the bamboo. For 2-month-old bamboo, the glucose content was highest in the 1st internode and lowest in the 11th. However, 


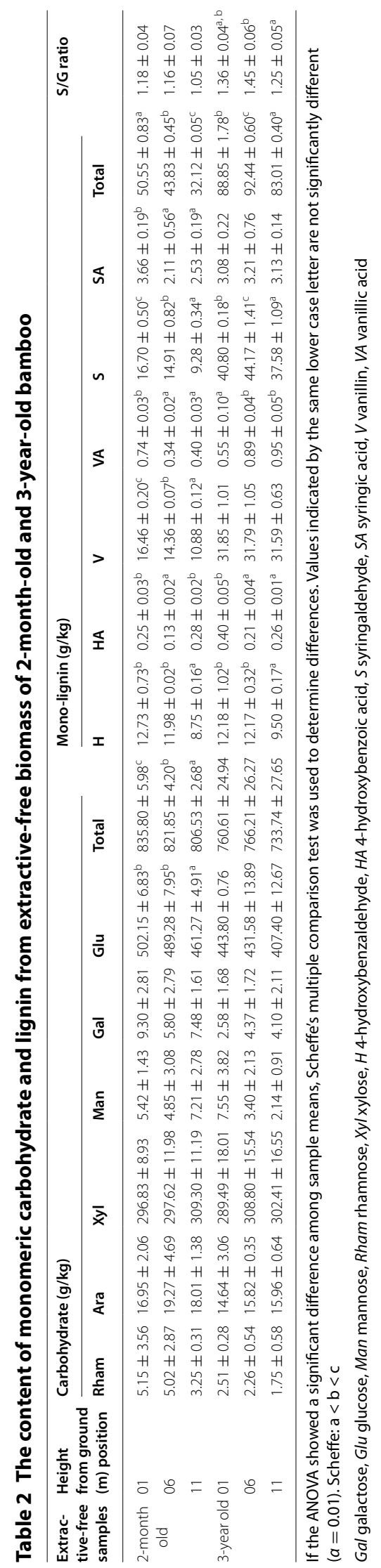


glucose contents in the different internodes of 3-yearold bamboo did not differ significantly. For 2-month-old bamboo, the lignin contents were 14.6-18.3\%; however, the contents were considerably higher in 3-year-old bamboo, ranging from 25.4 to $27.1 \%$. Furthermore, the syringyl-to-guaiacyl $(\mathrm{S} / \mathrm{G})$ ratio was higher in 3-yearold bamboo (1.25-1.45) than in 2-month-old bamboo (1.05-1.18). An increase of S/G ratio with plant maturity has been reported by Rencoret et al. [25]. The lignin content and lignin S/G ratio negatively related with enzymatic digestibility. Difference in biomass composition has a direct impact on bioenergy potential [26, 27]. In this regard, lignin $[28,29]$ and hemicelluloses [30] in herbaceous biomass have been shown to be negatively correlated with overall bioenergy yields. It is suggested that carbohydrate and lignin contents in bamboo, particularly at a young age, make it a useful source of biomass for bioenergy and other bio-based applications. The contents of monomeric sugars and lignin of pretreated bamboo are presented in Table 3. We focused on the three major components: glucose, xylose, and lignin. The total biomass weight of the pretreated bamboo decreased by $60-74 \%$. While the glucose remained intact, it relatively increased in residual biomass of 2-month-old (49.4 to $62.1 \%$ ) and 3-year-old bamboo (41.9 to $54.9 \%$ ) due to the removal of xylose and lignin. The carbohydrates of biomass are well preserved in the HPAC process, which is a very important criterion for a pretreatment process.

\section{Effects of stem height position on enzymatic hydrolysis}

Bamboo stems were divided into 1-m sections, and the relationship between their chemical composition and enzymatic hydrolysis yield was compared (Fig. 4). The saccharification yield was approximately eight times higher in 2-month-old bamboo than in 3-year-old bamboo. Reducing sugar concentration in the hydrolysate of 2-month-old bamboo was $0.7-1.9 \mathrm{mg} / \mathrm{mL}$, whereas that of 3-year-old bamboo was $0.1-0.2 \mathrm{mg} / \mathrm{mL}$. The saccharification pattern on each internode differed greatly between bamboos of the two different ages. Saccharification was the highest in the upper stem and the lowest in the lower position of 2-month-old bamboo, whereas in 3-year-old bamboo, it was higher in the upper and lower parts of the stem and lower in middle-stem region. Accordingly, at the same sample height, the saccharification yield was inversely related to the $S / G$ ratio on sample position (Table 2).

\section{Separate hydrolysis and fermentation (SHF)} and simultaneous saccharification and fermentation (SSF) SHF and SSF processes were performed at $5 \%(\mathrm{w} / \mathrm{v})$ solid loading (Fig. 5). In SHF process, enzymatic hydrolysis of HPAC-pretreated 2-month-old bamboo resulted in a
$28.6 \mathrm{~g} / \mathrm{L}$ glucose during $72 \mathrm{~h}$; corresponding to an overall glucose recovery of $91.8 \%$ (Fig. $5 \mathrm{a}$ ). In the case of 3-yearold bamboo, the final concentration and recovery of glucose were $27.9 \mathrm{~g} / \mathrm{L}$ and $88.6 \%$, respectively (Fig. 5b). After supplementation with yeast, the ethanol concentration in 2-month-old and 3-year-old bamboo reached 15.3 and $15.6 \mathrm{~g} / \mathrm{L}$, respectively, which was based on total glucose content in HPAC-pretreated biomass assuming 96.9 and 96.1\% fermentation yield within a 72-h period (Fig. 5a, b). Based on the theoretical yield of $0.51 \mathrm{~g}$ ethanol/g glucose, the final ethanol concentration after fermentation was higher than the amount of enzymatically released glucose in hydrolysates. The reason may be cellobiose which was hydrolyzed into glucose by $\beta$-glucosidase during the fermentation period. This assumption is in agreement with the previous report that enzymatic saccharification is not only a function of the raw biomass and enzyme cocktail, but it is also dependent on the required residence time [31]. In the SSF process, the SSF pattern in the bamboo of different ages was similar. The ethanol concentration in 2-month-old and 3-year-old bamboo after 72-h fermentation was 15.2 and $14.9 \mathrm{~g} / \mathrm{L}$, respectively, which was 96 and 93\% of the theoretical yield based on hexose conversion (Fig. 5c, d). However, ethanol fermentation of HPAC-pretreated bamboo achieved $307 \mathrm{~g}$ (2-monthold) and $257 \mathrm{~g}$ (3-year-old) of ethanol of $1 \mathrm{~kg}$ of initial raw biomass (Fig. 6). These results demonstrate that the biological conversion of young bamboo to ethanol is efficient with pretreatment.

\section{Conclusions}

Bamboo is considered a grass biomass material that has great potential as a future bioresource for biorefining. The bamboo of two different ages examined in the present study showed characteristics pattern in terms of morphology, chemical composition, and bioconversion. Two-month-old bamboo had a pattern of tissue organization similar to that of 3-year-old bamboo, indicating that it had reached its full height. There were significant differences in the chemical compositions of 2-month-old and 3-year-old bamboo. The glucose contents in 3-yearold bamboo did not differ significantly among its internodes. For 2-month-old bamboo, the lignin contents were $14.6-18.3 \%$, whereas those in 3-year-old bamboo were considerably higher, ranging from 25.4 to $27.1 \%$. Furthermore, S/G ratio was higher in 3-year-old bamboo compared to 2-month-old bamboo. Total sugar yield from enzymatic hydrolysis was approximately eight times higher in 2-month-old than in 3-year-old raw bamboo. The results of SHF and SSF for 2-month-old and 3-yearold bamboo after HPAC pretreatment were not significantly different. However, ethanol yield after HPAC pretreatment was higher in 2-month old than in 3-year 


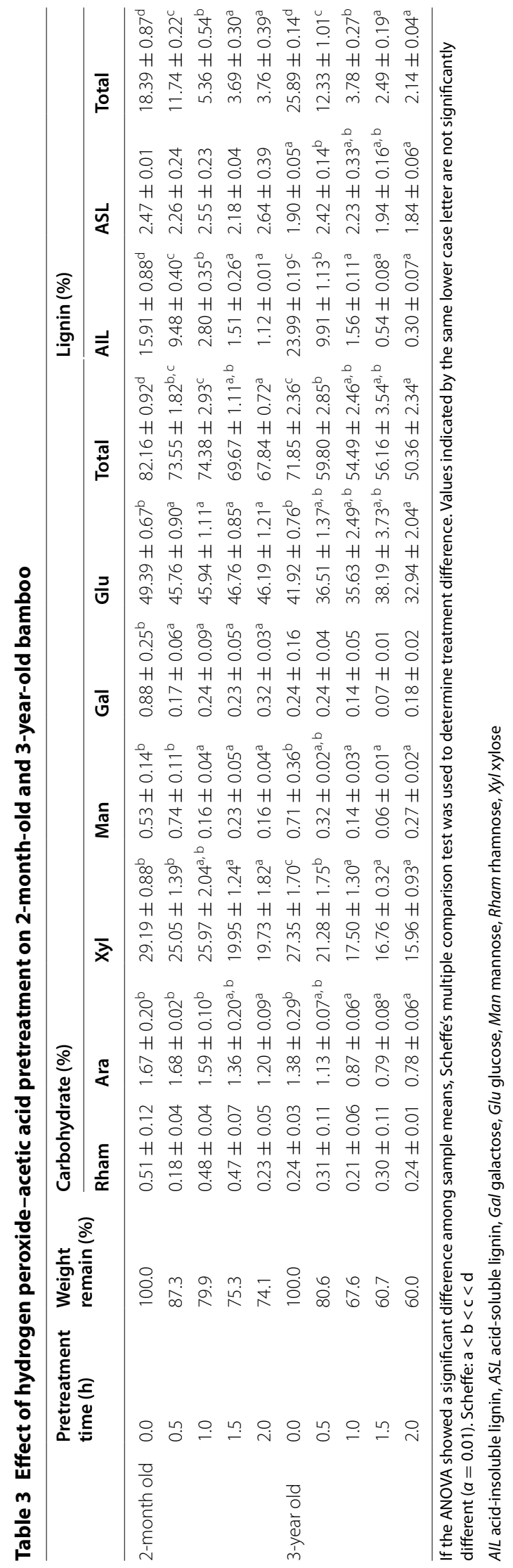



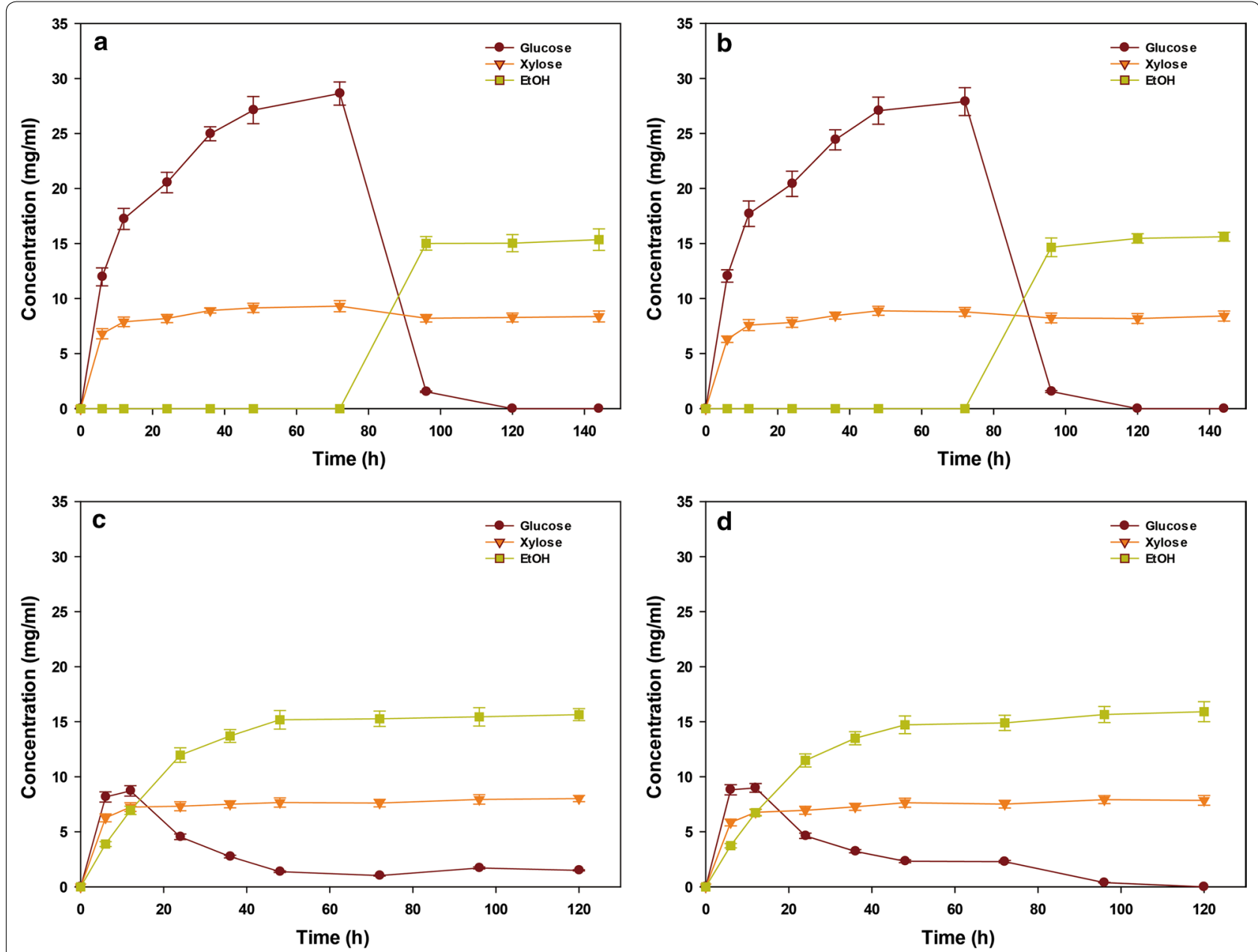

Fig. 5 Concentration profiles for SHF (a, b) and SSF (c, d) process of HPAC-pretreated 2-month-old (a, $)$ and 3-year-old (b, d) bamboo at 5\% solid loading

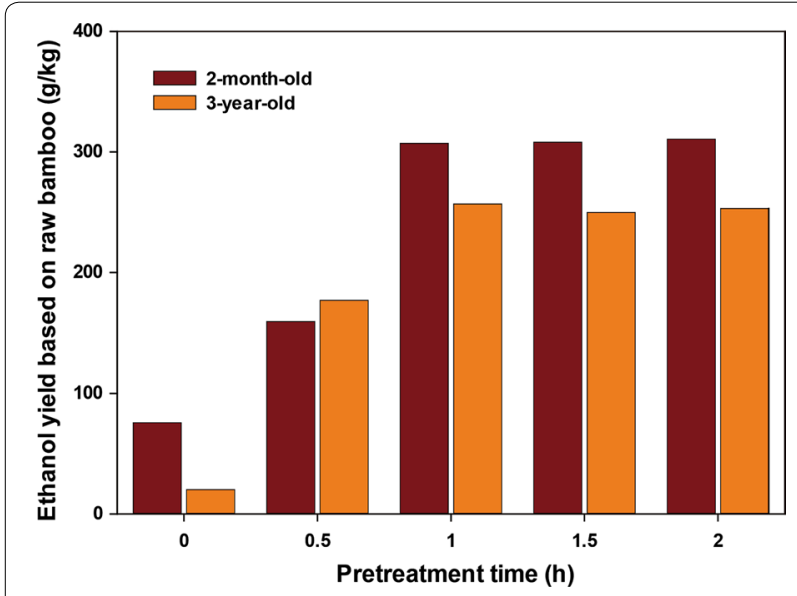

Fig. 6 Effect of pretreatment time on ethanol productivity based on the raw bamboo. Each value is expressed as the average of three independent experiments old from initial raw biomass. Our data showed that the productivity of total sugar from raw material was high in 2-month-old bamboo with low lignin content. In terms of short-rotation biomass production, bamboo culms harvested after termination of height growth are suitable for use as a biomass resource to achieve a high yield for bioconversion process.

\section{Methods}

\section{Biomass and pretreatment}

In this study, we used bamboos (Phyllostachys pubescens) of age 2 months and 3 years, grown at the campus of Chonnam National University in Gwangju, South Korea. Columns were harvested at the end of May 2016. The columns were subsequently subdivided into $1 \mathrm{~m}$ length, labeled 1(basal) to 13(top), and then freezedried. These bamboo samples were ground in a Willy 
Mill preferably to a particle size sufficiently small to pass through a 40-mesh to 60-mesh sieve.

Ground bamboo samples (positioned 1, 6, and $11 \mathrm{~m}$ above ground) were pretreated using HPAC method [21]. Briefly, the pretreatment solution was prepared by mixing hydrogen peroxide and acetic acid $(1: 1 ; \mathrm{v} / \mathrm{v})$. Ten grams of each sample were treated separately with $50 \mathrm{~mL}$ of the reagent and kept at $80^{\circ} \mathrm{C}$ for $2 \mathrm{~h}$. Pretreated samples for the chemical analysis and enzymatic saccharification were collected at 30-min intervals, washed extensively with distilled water until a neutral $\mathrm{pH}$ was attained, and then freeze-dried for $48 \mathrm{~h}$.

\section{Fluorescence microscopy}

Sections (10-20 $\mu \mathrm{m}$ thick) were cut transversely through bamboo stem at each height. Sections without staining were mounted in water and observed through autofluorescence. To compare the morphological and histochemical differences before and after pretreatment, cross-sections were pretreated using the above-mentioned condition and then gently washed with distilled water. Autofluorescence was recorded using a UV filter cube (excitation filter band pass 330 to $385 \mathrm{~nm}$ and barrier filter $420 \mathrm{~nm}$ ) [32].

\section{Chemical composition}

The chemical composition [Klason lignin (T $222 \mathrm{om}-88$ ), organic solvent extractives (T $204 \mathrm{om}-88$ ), and ash (T 211 om-85)] of raw and pretreated bamboo stem was analyzed in accordance with the TAPPI Standard Method [33].

\section{Structural carbohydrates}

Structural carbohydrate of samples was analyzed using gas chromatography $[6,34]$. Each sample was treated with sulfuric acid for $1 \mathrm{~h}$ at room temperature, and hydrolysis was performed at $121^{\circ} \mathrm{C}$ for $1 \mathrm{~h}$. Myo-inositol was added to the samples as an internal standard, and the mixture was neutralized with ammonia water. The reactant was reduced to alditols with sodium tetrahydroborate, and the excess sodium tetrahydroborate was decomposed with acetic acid. Alditols were acetylated with acetic anhydride through methylimidazole catalysis and then extracted with dichloromethane. This solution was analyzed using a gas chromatograph (GC2010; Shimadzu, Otsu, Japan) equipped with a DB-225 capillary column $(30 \mathrm{~m} \times 0.25 \mathrm{~mm}$ ID, $0.25-\mu \mathrm{m}$ film thickness, J \& W Scientific, CA, USA) operated with helium. The operation conditions were as follows: injector temperature $220^{\circ} \mathrm{C}$; flame ionization detector (FID) temperature $250{ }^{\circ} \mathrm{C}$; initial oven temperature $100{ }^{\circ} \mathrm{C}$ for $1.5 \mathrm{~min}$; and heating rate $5{ }^{\circ} \mathrm{C} / \mathrm{min}$ up to $220^{\circ} \mathrm{C}$ [6].

\section{Lignin monomers}

The lignin monomers were determined by alkaline nitrobenzene oxidation [35]. Thirty milligrams of sample in a $10-\mathrm{mL}$ stainless steel reactor were suspended in $4 \mathrm{~mL} \mathrm{NaOH}(2 \mathrm{M})$. To this mixture, $0.25 \mathrm{~mL}$ nitrobenzene was added, followed by heating at $170{ }^{\circ} \mathrm{C}$ for $2 \mathrm{~h}$. The reactor was then immediately placed in ice water, followed by the addition of $0.1 \mathrm{~mL}$ ethyl-vanillin $(50 \mathrm{mg} /$ $\mathrm{mL}$ ). After extraction with dichloromethane and ether, the solvent layer was transferred to a beaker filled with sodium sulfate to remove water, and was subsequently evaporated. The dried products were reacted with $\mathrm{N}, \mathrm{O}$ bis(trimethylsilyl)-acetamide at $105^{\circ} \mathrm{C}$ for $2-3 \mathrm{~min}$. The trimethylsilyl-derivatized solution was then analyzed using a gas chromatograph (CP-9100, Chrompack, The Netherlands) equipped with a CP-Sil 5CB-fused silica capillary column $(25 \mathrm{~m} \times 0.32 \mathrm{~mm}$ ID, $1.2-\mu \mathrm{m}$ film thickness, The Chrompack, Netherlands) operated with helium. The operation conditions were as follows: injector temperature $280{ }^{\circ} \mathrm{C}$; flame ionization detector (FID) temperature $280^{\circ} \mathrm{C}$; initial oven temperature $150{ }^{\circ} \mathrm{C}$ for $5 \mathrm{~min}$; and heating rate $10^{\circ} \mathrm{C} / \mathrm{min}$ up to $250^{\circ} \mathrm{C}$ [8].

\section{Enzyme assays and enzymatic hydrolysis}

Cellulase (Celluclast 1.5 L, Novozyme) and xylanase (X2753, Sigma) were used for enzymatic hydrolysis. Cellulase and xylanase activities were measured according to Adney and Baker [36] and Teixeira et al. [37], respectively. Enzyme activities for cellulase and xylanase were 69.4 filter paper units (FPU) $/ \mathrm{mL}$ and $979 \mathrm{IU} / \mathrm{mL}$, respectively.

Enzymatic hydrolysis was conducted at $1 \%$ dry matter $(\mathrm{DM}, \mathrm{w} / \mathrm{v})$ initial substrate loading in a $50-\mathrm{mL}$ conical tube. A substrate was soaked in $0.05 \mathrm{M}$ sodium citrate buffer $(\mathrm{pH} 5)$, with sodium azide $(0.2 \%, \mathrm{w} / \mathrm{v})$ added as an antibiotic to prevent microbial contamination. Enzymatic hydrolysis was performed at $37^{\circ} \mathrm{C}$ with an enzyme loading of $10 \mathrm{FPU}$ cellulase $/ \mathrm{g}^{1}$ biomass and $1000 \mathrm{IU}$ xylanase $/ \mathrm{g}^{1}$ biomass for $72 \mathrm{~h}$ [7]. The sugar contents in these hydrolysates were measured using DNS assay [38] and HPLC method [7].

\section{Separate hydrolysis and fermentation (SHF) and simultaneous saccharification and fermentation (SSF)} Enzymatic saccharification was conducted in a 500$\mathrm{mL}$ Erlenmeyer flask with a total working volume of $100 \mathrm{~mL}$ at a substrate concentration of $5 \% \mathrm{DM}(\mathrm{w} / \mathrm{v})$ with $0.1 \%(\mathrm{w} / \mathrm{v})$ yeast extract, $0.2 \%(\mathrm{w} / \mathrm{v})$ peptone, and $0.05 \mathrm{M}$ citrate buffer (pH 4.8). Reaction flasks were run with an enzyme loading of $10 \mathrm{FPU}$ cellulase and $1000 \mathrm{IU}$ xylanase/g biomass at $150 \mathrm{rpm}$. After $72 \mathrm{~h}$, Saccharomyces cerevisiae KCTC 7906 (50 mg of dry yeast) was added to $100 \mathrm{~mL}$ of hydrolysates. Fermentation was carried out 
at $32{ }^{\circ} \mathrm{C}$ for $72 \mathrm{~h}$ with agitation at $150 \mathrm{rpm}$ [7]. SSF was conducted in a $100 \mathrm{~mL}$ total volume containing $5 \% \mathrm{DM}$ $(\mathrm{w} / \mathrm{v})$, cellulase (10 FPU/g biomass), xylanase $(1000 \mathrm{IU} / \mathrm{g}$ biomass), $50 \mathrm{mg}$ dry yeast (S. cerevisiae KCTC 7906), $0.1 \%(\mathrm{w} / \mathrm{v})$ yeast extract, $0.2 \%(\mathrm{w} / \mathrm{v})$ peptone, and $0.05 \mathrm{M}$ citrate buffer $(\mathrm{pH} 4.8)$ at $37{ }^{\circ} \mathrm{C}$ for $120 \mathrm{~h}$ in a $500-\mathrm{mL}$ Erlenmeyer flask [8].

Sugars (glucose and xylose) and ethanol produced during SHF and SSF processes were monitored using an HPLC system equipped with a refractive index detector (YoungLin Instruments, Anyang, Korea). A Rezex ROA organic acid column $(300 \times 7.8 \mathrm{~mm}$, Phenomenex, Torrance, CA) was used for compound identification. The temperatures of the column and detector were maintained at 65 and $40{ }^{\circ} \mathrm{C}$, respectively, and $5 \mathrm{mM}$ sulfuric acid was used as the mobile phase [7]. Fermentation efficiency was calculated on the basis of total glucose content in the pretreated materials by dividing the quantity of ethanol produced by the total amount of glucose.

\section{Data analysis}

The SPSS software was used for statistical analysis. Oneway ANOVA was used to test. Additionally, the Scheffe's test (at $\alpha=0.01$ ) was applied to detect differences in group means.

\begin{abstract}
Abbreviations
AlL: acid-insoluble lignin; ASL: acid-soluble lignin; DM: dry matter; FPU: filter paper unit; Gal: galactose; GC: gas chromatography; Glu: glucose; Man: mannose; $\mathrm{H}$ : 4-hydroxybenzaldehyde; HA: 4-hydroxybenzoic acid; HPLC: high-performance liquid chromatography; HPAC: hydrogen peroxide-acetic acid; IU: International unit; OSE: organic solvent extractives; Rham: rhamnose; S: syringaldehyde; SA: syringic acid; SHF: separate hydrolysis and fermentation; S/G ratio: syringyl-to-guaiacyl ratio; SSF: simultaneous saccharification and fermentation; V: vanillin; VA: vanillic acid; Xyl: xylose.
\end{abstract}

\section{Authors' contributions}

SGW performed the lab-scale pretreatment, enzymatic hydrolysis, and chemical composition analyses including the HPLC and GC. SGW also wrote and revised the manuscript. DSL and QAN carried out the ethanol fermentation and the determination of ethanol content. HJB coordinated the study, contributed to the analysis of the results and to revisions of the manuscript. All authors read and approved the final manuscript.

\section{Author details}

${ }^{1}$ Bio-Energy Research Center, Chonnam National University, Gwangju 500-757, Republic of Korea. ${ }^{2}$ Department of Bioenergy Science and Technology, Chonnam National University, Gwangju 500-757, Republic of Korea.

\section{Acknowledgements}

Not applicable.

\section{Competing interests}

The authors declare that they have no competing interests.

\section{Availability of supporting data}

The datasets generated and analyzed during the current study are available from the corresponding author upon reasonable request.

\section{Consent for publication}

All authors approved the publication of this manuscript.

\section{Funding}

This work was supported by Priority Research Centers Program (20100020141) through the National Research Foundation of Korea (NRF) funded by the Ministry of Education, Science and Technology, Republic of Korea. Also, this work was supported by the National Research Foundation of Korea (NRF) grant funded by the Korea government (MSIP) (No. 2015R1A2A2A01004594).

\section{Publisher's Note}

Springer Nature remains neutral with regard to jurisdictional claims in published maps and institutional affiliations.

Received: 6 February 2017 Accepted: 10 May 2017

Published online: 15 May 2017

\section{References}

1. Lee JS, Lee JP, Park JY, Lee JH, Park SC. Status and perspectives on bioenergy in Korea. Renew Sustain Energy Rev. 2011;15:4884-90.

2. Ertugrul HM, Cetin M, Seker F, Dogan E. The impact of trade openness on global carbon dioxide emissions: evidence from the top ten emitters among developing countries. Ecol Indic. 2016;67:543-55.

3. Korea Energy Management Corporation. New and renewable energy statistics 2015. (Text in Korean).

4. Kim SJ, Kim Y, Jeong SJ, Jang MS, Chung IM. Analysis of the biomass content of various Miscanthus genotypes for biofuel production in Korea. Ind Crops Prod. 2012;38:46-9.

5. Kim KH, Choi IS, Kim HM, Wi SG, Bae H-J. Bioethanol production from the nutrient stress-induced microalga Chlorella vulgaris by enzymatic hydrolysis and immobilized yeast fermentation. Bioresour Technol. 2014;153:47-54.

6. Wi SG, Kim HJ, Mahadevan SA, Yang D-J, Bae H-J. The potential value of the seaweed Ceylon moss (Gelidium amansii) as an alternative bioenergy resource. Bioresour Technol. 2009;100:6658-60.

7. Wi SG, Choi IS, Kim KH, Bae H-J. Bioethanol production from rice straw by popping pretreatment. Biotechnol Biofuels. 2013;6:116.

8. Wi SG, Kim S-B, Lee D-S, Kim HM, Bae H-J. A comparative study on enzymatic hydrolysis of kenaf from two different harvest time-points, withand without pretreatment. Ind Crops Prod. 2015;76:237-43.

9. Fuwape JA, Akindele SO. Biomass yield and energy value of some fastgrowing multipurpose trees in Nigeria. Biomass Bioenergy. 1997;12:101-6.

10. Stolarski MJ, Szczukowskia S, Tworkowskia J, Klasa A. Yield, energy parameters and chemical composition of short-rotation willow biomass. Ind Crops Prod. 2013;46:60-5.

11. Littlewood J, Wang L, Turnbull C, Murphy RJ. Techno-economic potential of bioethanol from bamboo in China. Biotechnol Biofuels. 2013;6:173.

12. Liu Z, Hu W, Jiang Z, Mi B, Fei B. Investigating combustion behaviors of bamboo, torrefied bamboo, coal and their respective blends by thermogravimetric analysis. Renew Energy. 2016;87:346-52.

13. Scurlock JMO, Dayton DC, Hames B. Bamboo: an overlooked biomass resource? Biomass Bioenergy. 2000;19:229-44.

14. Liu ZJ, Jiang ZH, BH Fei, Cai ZY, Liu XE, Yu Y. Bamboo pellets: a potential and commercial pellets in China. Sci Silvae Sin. 2012;48:133-9.

15. Yen TM. Culm height development, biomass accumulation and carbon storage in an initial growth stage for a fast-growing moso bamboo (Phyllostachy pubescens). Bot Stud. 2016;57:10.

16. Yen TM, Ji YJ, Lee JS. Estimating biomass production and carbon storage for a fast-growing makino bamboo (Phyllostachys makinoi) plant based on the diameter distribution model. For Ecol Manage. 2010;260:339-44.

17. Suzuki K, Itoh T. The changes in cell wall architecture during lignification of bamboo, Phyllostachys aurea Carr. Tree. 2001;15:137-47.

18. Yen TM, Lee JS. Comparing aboveground carbon sequestration between moso bamboo (Phyllostachys heterocycla) and China fir (Cunninghamia lanceolata) forests based on the allometric model. For Ecol Manage. 2011:261:995-1002. 
19. Jiang Z, Fei B, Li Z. Pretreatment of bamboo by ultra-high pressure explosion with a high-pressure homogenizer for enzymatic hydrolysis and ethanol fermentation. Bioresour Technol. 2016;214:876-80.

20. Ma X, Zheng $X$, Yang $H$, Wu H, Cao S, Chen L, Huang L. A perspective on lignin effects on hemicelluloses dissolution for bamboo pretreatment. Ind Crops Prod. 2016;94:117-21.

21. Wi SG, Cho EJ, Lee D-S, Lee SJ, Lee YJ, Bae H-J. Lignocellulose conversion for biofuel: a new pretreatment greatly improves downstream biocatalytic hydrolysis of various lignocellulosic materials. Biotechnol Biofuels. 2015;8:228.

22. Huang XY, Qi JQ, Xie JL, Hao JF, Qin BD, Chen SM. Variation in anatomical characteristics of bamboo, Bambusa rigida. Sains Malays. 2015;44:17-23.

23. Tanger P, Vega-Sánchez ME, Fleming M, Tran K, Singh S, Abrahamson JB, Jahn CE, Santoro N, Naredo EB, Baraoidan M, Danku JMC, Salt DE, McNally KL, Simmons BA, Ronald PC, Leung H, Bush DR, McKay JK, Leach JE. Cell wall composition and bioenergy potential of rice straw tissues are influenced by environment, tissue type, and genotype. Bioenergy Res. 2015;8:1165-82.

24. Rancour DM, Marita JM, Hatfield RD. Cell wall composition throughout development for the model grass Brachypodium distachyon. Front Plant Biotechnol. 2012;3:266.

25. Rencoret J, Gutierrez A, Nieto L, Jimenez-Barbero L, Faulds CB, Kim H, Ralph J, Martínez AT, del Río JC. Lignin composition and structure in young versus adult Eucalyptus globulus plants. Plant Physiol. 2011;155:667-82.

26. Ioelovich M. Correlation analysis of enzymatic digestibility of plant biomass. Biomass Convers Biorefin. 2014;4:269-75.

27. Studer MH, DeMartini JD, Davis MF, Sykes RW, Davison B, Keller M, Tuskan GA, Wyman CE. Lignin content in natural Populus variants affects sugar release. Proc Natl Acad Sci. 2011;108:6300-5.

28. Lv S, Yu Q, Zhuang X, Yuan Z, Wang W, Wang Q, Qi W, Tan X. The influence of hemicellulose and lignin removal on the enzymatic digestibility from sugarcane bagasse. Bioenergy Res. 2013;6:1128-34.
29. Bottcher A, Cesarino I, Santos AB, Vicentini R, Mayer JLS, Vanholme R, Morreel K, Goeminne G, Moura JCMS, Nobile PM, Carmello-Guerreiro SM, Anjos IA, Creste S, Boerjan W, de Andrade Landell MG, Mazzafera P. Lignification in sugarcane: biochemical characterization, gene discovery and expression analysis in two genotypes contrasting for lignin content. Plant Physiol. 2013;163:1539-57.

30. Xu N, Zhang W, Ren S, Liu F, Zhao c, Liao H, Xu Z, J Huang, Qing L, Tu Y, Bin $Y$, Wang Y, Jiang J, Qin J, Peng L. Hemicelluloses negatively affect lignocellulose crystallinity for high biomass digestibility under $\mathrm{NaOH}$ and $\mathrm{H}_{2} \mathrm{SO}_{4}$ pretreatments in Miscanthus. Biotechnol Biofuels. 2012;5:1-12.

31. Marques $S$, Alves L, Roseir JC, Gírio FM. Conversion of recycled paper sludge to ethanol by SHF and SSF using Pichia stiptis. Biomass Bioenergy. 2011;35:1600-6.

32. Song Y, Wi SG, Kim HM, Bae H-J. Cellulosic bioethanol production from Jerusalem artichoke (Helianthus tuberosus $\mathrm{L}$.) using hydrogen peroxideacetic acid (HPAC) pretreatment. Bioresour Technol. 2016;214:30-6.

33. TAPPI Committee. TAPPI test methods. TAPPI Press: Atlanta;1992.

34. Blakeney AB, Harris PJ, Henry RJ, Stone BA. A simple and rapid preparation of alditol acetates for monosaccharide analysis. Carbohydr Res. 1983:113:291-9.

35. liyama K, Wallis AFA. Determination of lignin in herbaceous plants by an improved acetyl bromide procedure. J Sci Food Agric. 1990;51:145-461.

36. Adney B, Baker J. Measurement of cellulose activities. National Renewable Energy Laboratory (NREL). 2008.

37. Teixeira RSS, Siqueira FG, Souza MVD, Filho EXF, Bon EPDS. Purification and characterization studies of a thermostable $\beta$-xylanase from Aspergillus awamori. J Ind Microbiol Biotechnol. 2010;37:1041-51.

38. Miller GL. Use of dinitrosalicylic acid reagent for determination of reducing sugar. Anal Chem. 1959;13:426-8.

\section{Submit your next manuscript to BioMed Central and we will help you at every step:}

- We accept pre-submission inquiries

- Our selector tool helps you to find the most relevant journal

- We provide round the clock customer support

- Convenient online submission

- Thorough peer review

- Inclusion in PubMed and all major indexing services

- Maximum visibility for your research

Submit your manuscript at www.biomedcentral.com/submit
() BioMed Central 